\title{
Les composantes culturelles des premières productions céramiques au Bronze ancien dans le sud-est de la France : le cas de l'Auvergne
}

Joël Vital

\section{(2) OpenEdition}

\section{Journals}

Édition électronique

URL : http://journals.openedition.org/adlfi/4773

ISSN : 2114-0502

Éditeur

Ministère de la culture

Référence électronique

Joël Vital, « Les composantes culturelles des premières productions céramiques au Bronze ancien dans le sud-est de la France : le cas de l'Auvergne », ADLFI. Archéologie de la France - Informations [En ligne], Auvergne, mis en ligne le 01 mars 2006, consulté le 03 mai 2019. URL : http:// journals.openedition.org/adlfi/4773

Ce document a été généré automatiquement le 3 mai 2019.

(c) Ministère de la Culture et de la Communication, CNRS 


\section{Les composantes culturelles des premières productions céramiques au Bronze ancien dans le sud-est de la France : le cas de l'Auvergne}

Joël Vital

Identifiant de l'opération archéologique : 109

Date de l'opération : 2003 - 2007 (PC)

1 Les travaux du PCR « Composantes culturelles des premières productions céramiques du Bronze ancien dans le sud-est de la France » qui se sont déroulés en 2006 clôturent un cycle de trois années de travaux initiés en 2003 (BSR 2003, p. 124 ; BSR 2004, p. 212 ; BSR 2005, p. 136). Quelques prolongements seront probablement nécessaires en 2007 pour des raisons de difficultés d'accès à certains mobiliers, mais qui ne concernent que des sites secondaires.

2 Cette dernière année d'analyse documentaire sur l'Auvergne a vu le déroulement de trois opérations distinctes.

3 - L'examen de séries qui ne présentaient pas a priorid'intérêt immédiat dans le cadre de ce PCR, soit par l'extrême réduction des corpus (Le Puy-en-Velay - Chirel, par exemple), soit parce que relevant potentiellement de phases plus tardives du Bronze ancien ou du Bronze moyen (Riom - PEER II, par exemple). Dans ces derniers cas, l'objectif était plutôt d'isoler par exclusion la phase ancienne du Bronze ancien. Les inventaires ont visé ensuite à alimenter une base de données en cours de constitution, qui fera l'objet de futurs développements spécifiques centrés sur la période de Bronze moyen.

4 - Un complément d'observations sur le mobilier du vaste site de Clermont-Ferrand - La Grande Borne. Après les vestiges tirés des opérations préventives récentes (BSR 2002, p. 98-99, Christine Vermeulen ; BSR 2002, p. 99 et BSR 2003, p. 74-78, 
Frédérique Blaizot) traités en 2005, nous avons analysé les céramiques issues des fouilles John Collis. Nous avons bénéficié pour cela du travail d'inventaire réalisé par Cathy Georjon et Frédéric Jallet dans le cadre de l'ACR Néolithique d'Auvergne qu'ils pilotent. Alors qu'aucun vestige du Bronze ancien n'avait été identifié parmi le mobilier des fouilles récentes, nous avons pu isoler quelques pièces du premier stade (BA 1) cette année.

5 - Le retour sur l'ensemble des pièces exhumées des fouilles de Gilles Loison sur le site d'Orcet - Le Tourteix (fouilles 1981-1985), auxquelles il nous a enfin été possible d'accéder cette année, malgré quelques lacunes (absence de certains tessons décorés ou de deux vases «bien " conservés).Ce réexamen permet une vision totalement renouvelée de la chronologie et des composantes culturelles de ce gisement. Il constitue la clef de voûte des trois années de déroulement du PCR en Auvergne.

6 Un second volet concerne la poursuite des analyses pétrographiques des échantillons recueillis, limités aux céramiques relevant de la phase ancienne du Bronze ancien, réalisées par Fabien Convertini (INRAP Méditerranée).Ce travail sera encore poursuivi en 2007 par le traitement des échantillons rassemblés cette année (Orcet - Le Tourteix principalement), alors que le bilan synthétique ne pourra guère intervenir avant 2008.

7 Les principaux résultats des recherches conduites en 2006concernent le site d'Orcet - Le Tourteixet peuvent être résumés ainsi.

8 - Quelques tessons signalent une présence antérieure au Bronze ancien, du Néolithique ancien et du Campaniforme.

9 - Nous pouvons isoler nettement ensuite deux temps d'occupation postérieurs au Campaniforme :

10 - le plus récent correspond assez bien au corpus mis en évidence sur le gisement de La Roche-Blanche - Beauséjour, à quelques kilomètres seulement à l'ouest d'Orcet. La position réelle en chronométrie de ce "style Beauséjour", terme que nous pouvons avancer pour caractériser cette production, n'est pas encore fixée. Ses composantes culturelles ne permettent pas encore, si une position dans le XVI es. av. J.-C. peut être postulée, de décider s'il s'agit d'un premier stade du Bronze moyen, qu'il définirait, ou d'une phase terminale du Bronze ancien. Nous rejoignons là les questionnements de portée plus générale induits par le réexamen du mobilier et de la séquence du tumulus $n$ - 1 de la nécropole de Lair à Laurie (Cantal).

11 - une phase plus ancienne du Bronze ancien peut être isolée, sans équivoque cette fois. Elle est identifiée à partir de la confrontation avec le contenu de deux ensembles régionaux : ceux de la fosse 5 de La Roche-Blanche - Les Vignes et des structures 19 et 2 de Pont-du-Château - Chazal. Les seules structures qui relèveraient in fined'un premier stade du Bronze ancien seraient les structures E2, E3, E6, F11 et F1.

12 - Des héritages taphonomiques ont été notés à plusieurs reprises par la présence de céramiques asynchrones dans des fosses.

13 - La fragmentation des tessons à décor incisé, croisillonné ou barbelé, pourrait être indicatrice. Les pièces de taille réduite semblent en position secondaire dans des structures d'âge plus récent. Un plus gros fragment est issu de la structure E3, qui semble à rapporter à une phase ancienne du Bronze ancien. Le seul profil à décor barbelé connu provient hélas d'un décapage de surface. 
14 En conclusion, l'homogénéité initialement postulée des productions céramiques du site d'Orcet - Le Tourteix et une occupation resserrée sur le seul Bronze ancien sont remises en question. Les mobiliers livrés par plusieurs structures ne peuvent être considérés comme synchrones à cause d'héritages taphonomiques issus de périodes antérieures. Au moins quatre phases d'occupations ont été discriminées : Néolithique ancien, Néolithique final campaniforme, Bronze ancien stade ancien, Bronze ancien stade récent à Bronze moyen 1. Ces développements devront être pris en compte dans l'interprétation de l'histoire globale des implantations du site du Tourteix. Cependant, les deux premières périodes de fréquentation des lieux (Néolithique ancien, Néolithique final campaniforme) ne semblent pas avoir été marquées par la réalisation d'aménagements évidents. Des six datations radiocarbone connues, une seule est recevable pour le Bronze ancien en regard $\mathrm{du}$ mobilier livré, celle de la structure F11 (Lyon-4:3535 BP $\pm 70 \mathrm{BP}$, soit vers 1885-1780 avant J.-C.). Une seconde s'accorde avec une chronométrie proche, en surface, niveaux 4/5, mais sans céramique directement associée (Ly-3408:3590 $\mathrm{BP} \pm 110 \mathrm{BP}$, soit vers 1945-1880 avant J.-C.).Les datations obtenues pour les structures $\mathrm{E} 1$ et $\mathrm{F} 3$ à mobilier bronze ancien, correspondant à la fin du Néolithique, sont donc trop anciennes. Elles peuvent avoir été faites sur des échantillons hérités de formations antérieures. L'excavation E1 livre d'ailleurs un fragment de fond polypode qui s'apparente plus aux formes du Campaniforme que du Bronze moyen régional. Une seconde date de la structure $\mathrm{F} 3$ est plus compatible avec un âge de transition Bronze ancien-Bronze moyen; mais elle est peu précise, pour une période où la courbe de calibration connaît un palier. Enfin, la sépulture T1 relève du Bronze moyen. On peut noter à ce propos que ce dépôt sépulcral en fosse succède à un cycle d'occupation à statut semble-t-il d'habitat.

$15 \mathrm{Au}$ moment où nous rédigeons, les mesures radiocarbone - une dizaine - en cours sur plusieurs séries d'Auvergne étudiées ces trois dernières années ne nous sont pas encore parvenues. Tout nouveau commentaire chronométrique ou chronologique est donc prématuré.

\section{INDEX}

Index géographique : Auvergne

peuple Campaniforme

Index chronologique : Bronze ancien, Bronze moyen, Néolithique ancien

Thèmes : analyse documentaire, base de données, céramique du bronze, chronologie, décor incisé, inventaire, minéralogie, motif décoratif, pétrographie, production, radiocarbone,

sépulture, tumulus, vase polypode

operation Projet collectif de recherche (PCR) 
AUTEUR

JOËL VITAL

CNRS 